\title{
Penanaman Kemandirian Anak Melalui Pembelajaran Di Sentra Balok
}

\author{
Riskia Fitriani ${ }^{1}$; Rohita ${ }^{1}$ \\ ${ }^{1}$ Program Studi Pendidikan Guru Pendidikan Anak Usia Dini, Fakultas Psikologi dan Pendidikan, \\ Universitas Al Azhar Indonesia, Kompleks Masjid Agung Al Azhar Jalan Sisingamangaraja Kebayoran Baru, \\ Jakarta, 12110
}

Penulis untuk Korespondensi/E-mail:rohita@uai.ac.id

\begin{abstract}
Abstrak- Kemandirian merupakan salah satu karakter yang perlu dimiliki dan ditanamkan kepada anak sejak dini. Adapun tujuan penelitian ini adalah untuk mendeskripsikan upaya yang dilakukan dalam penanaman kemandirian anak melalui pembelajaran di sentra balok Taman Kanak-kanak Islam Al Azhar 45 Grand Depok City. Metode penelitian yang digunakan adalah kualitatif dengan pendekatan kualitatif deskriptif. Pengumpulan data dilakukan dengan wawancara, observasi dan dokumentasi. Sumber data pada penelitian ini adalah kepala sekolah, guru dan anak-anak Kelompok A4 di sentra balok Taman Kanak-Kanak Islam Al Azhar 45 Grand Depok City. Analisis data dilakukan dengan menggunakan teknik analisis data Model Interaktif dari Miles and Huberman yang meliputi reduksi data, penyajian data dan verifikasi data. Data disajikan dalam bentuk narasi dan gambar. Hasil penelitian menunjukkan bahwa penanaman kemandirian anak melalui pembelajaran di sentra balok Taman Kanak-Kanak Islam Al Azhar 45 Grand Depok City dilakukan dengan penerapan aturan main secara konsisten pada saat pijakan sebelum main, yang meliputi aturan: 1. ambil dan kembalikan balok pada tempatnya; 2 . Jaga baloknya; 3. baloknya berbagi dengan teman; dan 4 . ambil balok secukupnya.
\end{abstract}

Abstract - Independence is the character which is important to be instilled in children from an early age. The purpose of this study is to describe how the independence of children is build through learning in the beam center of Al Azhar 45 Islamic Kindergarten Grand Depok City. This research used qualitative method with a descriptive approach. Data collection through interviews, observations and documentations method. The data sources in this study are from the A4 school principals, teachers and children at the Al Azhar 45 Islamic Kindergarten Center Grand Depok City. Data analysis was carried out using the Interactive Model data analysis techniques by Miles and Huber which included data reduction, data presentation and data verification. The data presented in form the narratives and images. The results showed that building the children's independence through learning in the beam center of $\mathrm{Al}$ Azhar 45 Islamic Kindergarten Grand Depok City was carried out by applying the rules of the game consistently on the footing before playing, which included rules: 1 . Take and return the beams in its place; 2.Taking care the beams; 3 . Shared the beams with friends; and 4 . Take the beams as much as needs it

Keywords - Block Centre, Independence, Learning,

\section{PENDAHULUAN}

\footnotetext{
A nak usia dini merupakan anak yang berada pada rentang keemasan, dimana berbagai stimulasi yang diberikan pada waktu tersebut dapat meningkatkan berbagai aspek perkembangan anak. Salah satu aspek perkembangan yang harus distimulasi adalah perkembangan sosial emosional, dimana kemandirian menjadi salah satu indikator capaian yang harus dilalui anak.
}

Kemandirian merupakan suatu keadaan dimana seseorang mampu melakukan berbagai kegiatannya dan melakukan berbagai hal untuk pemenuhan kebutuhannya tanpa memerlukan bantuan orang lain. Bahkan, dengan kemandiriannya pula, seseoran akan mampu menjadi solusi bagi kebutuhan orang lain. Pentingnya memiliki kemandirian, menjadikan alasan perlunya hal tersebut ditanamkan pada anak sejak dini. Kemandirian tidak akan muncul dengan sendirinya. Perlu ada upaya terus menerus dari 
pendidik, baik orangtua maupun guru dalam proses penanamannya.

\begin{abstract}
Kemandirian
Kemandirian merupakan salah satu aspek yang harus dimiliki setiap individu. Menurut Hurlock (dalam Yusuf), kemandirian adalah individu yang memiliki sikap mandiri dalam cara berpikir dan bertindak, mampu mengambil keputusan, mengarahkan dan mengembangkan serta menyesuaikan diri sesuai dengan norma yang berlaku di lingkungannya. Sementara menurut Monks, orang yang mandiri akan memperlihatkan perilaku yang eksploratif, mampu mengambil keputusan, percaya diri dan kreatif. Selain itu juga mampu bertindak kritis, tidak takut berbuat sesuatu, mempunyai kepuasan dalam melakukan aktifitasnya, mampu menerima realita serta dapat memanipulasi lingkungan, berinteraksi dengan teman sebaya, terarah pada tujuan dan mampu mengendalikan diri. [1][2]
\end{abstract}

Kemandirian pada anak usia dini berbeda dengan kemandirian pada remaja atau orang dewasa. Di dalam buku Kerangka Dasar Kurikulum Pendidikan Anak Usia Dini yang dikeluarkan oleh Pusat Kurikulum Balitbang Depniknasseorang anak dapat dikatakan memiliki sikap kemandirian apabila anak mampu berinteraksi, mulai mematuhi aturan, dapat mengendalikan emosinya, menunjukkan rasa percaya diri, dan dapat menjaga diri sendiri. Sikap tersebut dapat dilihat ketika anak menjalani berbagai aktivitas sederhana baik di rumah maupun di sekolah. [3] Sebagai contoh ketika anak sudah tidak menangis lagi saat berpisah dengan orang tuanya untuk masuk sekolah. Contoh lainnya adalah ketika anak sudah mampu mengungkapkan keinginannya untuk ke kamar mandi dan ketika anak sudah bisa makan sendiri, menggunakan pakaian sendiri, serta memmakai sepatu sendiri.

Kemandirian sangat penting dikembangkan pada anak sejak usia dini agar anak menjadi individu yang mampu melakukan semua kegiatan dengan kemampuan dirinya sendiri tanpa campur tangan orang lain. Untuk itu orang tua dan orang dewasa disekitar anak harus memberikan bimbingan dan arahan kepada anak untuk mempersiapkan mereka mengarungi kehidupan di masa mendatang.

Pentingnya menumbuhkan kemandirian sejak anak usia dini dikemukakan oleh Kartono (dalam Fadholi) yang mengatakan bahwa potensi yang harus dikembangkan adalah kemandirian, karena pada usia prasekolah anak sudah mulai belajar memisahkan diri dari keluarga dan orang tuanya untuk memasuki suatu lingkungan yang lebih luas yaitu lingkungan taman kanak-kanak atau taman bermain. [4]

\section{Bentuk dan Ciri-ciri Kemandirian}

Menurut Nurfalah ada beberapa bentuk kemandirian anak, yaitu: a. Kemandirian fisik, yaitu kemampuan untuk mengurus dirinya sendiri; dan, $b$. Kemandirian psikologis, yaitu kemampuan untuk membuat keputusan dan memecahkan masalah yang dihadapi. Kemandirian dapat terlihat dengan memperhatikan ciri-ciri dari kemampuan dan sikap individu itu sendiri. [5] Laman, Avery \& Frank (dalam Budinurani) menyebutkan ciri-ciri individu yang mandiri adalahsebagai berikut [6]:

a. Memiliki kemampuan untuk mengambil keputusan tanpa pengaruh dari orang lain

b. Dapat berhubungan baik dengan orang lain

c. Memiliki kemampuan untuk bertindak sesuai dengan apa yang diyakini

d. Memiliki kemampuan untuk mencari dan mendapatkan kebutuhannya tanpa bantuan orang lain

e. Dapat memilih apa yang seharusnya dilakukan dan apa yang seharusnya tidak dilakukan

f. Kreatif dan berani dalam mencari dan menyampaikan ide-idenya

g. Memiliki kebebasan pribadi untuk mencapai tujuan hidupnya

h. Berusaha untuk mengembangkan dirinya.

i. Dapat menerima kritikan untuk mengevaluasi dirinya.

Dilihat dari sudut pandang seorang anak, Martinis \& Jamilah menjelaskan ciri-ciri anak yang mandiri untuk ukuran anak usia dini adalah sebagai berikut: a) Dapat melakukan segala aktifitasnya secara sendiri meskipun tetap dengan pengawasan orang dewasa, b) Dapat membuat keputusan dan pilihan sesuai dengan pandangan, pandangan itu sendiri diperolehnya dari melihat perilaku atau perbuatan orang-orang disekitarnya, c) Dapat bersosialisasi dengan orang lain tanpa perlu ditemani orang tua, d) Dapat mengontrol emosinya bahkan dapat berempati terhadap orang lain. [7]

Namun, ketidakmandirian anak masih sering ditemui saat ini, seperti contoh masih banyaknya anak yang tidak mau berpisah dengan ibunya ketika di sekolah, bahkan sampai merengek dan menangis. Hal tersebut akan menyebabkan kelak anak menjadi sulit beradaptasi dengan lingkungan. Contoh lainnya adalah masih banyak anak yang tidak mau 
mengerjakan tugas yang diberikan guru di sekolah, anak seringkali mengatakan tidak bisa dan tidak mau mencoba. Hal tersebut menunjukkan bahwa anak masih belum dapat menyelesaikan masalah sederhananya sendiri.

Hasil penelitian yang dilakukan oleh Ambarsari, Syukri dan Miranda pada tahun 2014 yang berjudul Peningkatan Kemandirian Anak Melalui Metode Pembiasaan Usia 4-5 Tahun di Taman Kanak-Kanak Mujahidin I, juga menunjukkan bahwa tingkat kemandirian anak masih rendah, terdapat 21 anak dari 25 anak (84\%) mengalami kesulitan dalam menyimpan sepatu di tempatnya, terdapat 18 anak dari 25 anak (72\%) mengalami kesulitan dalam membuka bekal sendiri, terdapat 15 anak dari 25 anak (60\%) yang mengalami kesulitan dalam mengembalikan mainan pada tempatnya setelah digunakan. [8]

Upaya pemerintah untuk mengatasi permasalahan pada anak usia dini khususnya masalah kemandirian adalah dengan menjadikan kemandirian sebagai salah satu karakter yang menjadi target pendidikan di Indonesia. Berdasarkan Undang-Undang Sistem Pendidikan Nasional Nomor 20 Tahun 2003 Pasal 3, dituliskan bahwa tujuan pendidikan di Indonesia adalah berkembangnya potensi peserta didik agar menjadi manusia yang beriman dan bertakwa kepada Tuhan Yang Maha Esa, berakhlak mulia, sehat, berilmu, cakap, kreatif, mandiri, dan menjadi warga untuk membentuk watak serta peradaban bangsa yang bermartabat. Di dalam undang-undang tersebut dapat dimaknai bahwa kemandirian harus dapat dicapai, diantaranya melalui pendidikan. [9] Berdasarkan hasil observasi yang dilakukan bulan Oktober pada anak kelompok A TK Islam Al Azhar 45 Grand Depok City, diketahui bahwa, sekolah sudah memberikan pembelajaran untuk menanamkan sikap kemandirian pada anak. Hal tersebut terlihat pada pola interaksi antara guru dengan anak dan anak dengan lingkungannya. Salah satu contoh adalah ketika waktu makan, ada seorang anak yang menumpahkan air minumnya, kemudian anak tersebut segera mencari kanebo dan mengelap air hingga kering, setelah selesai ia tidak lupa mengembalikan kanebo ke tempat semula. Peristiwa tersebut menunjukkan anak mengetahui apa yang terjadi, apa yang harus dilakukan, dan bagaimana melakukannya. Hal tersebut dilakukan sendiri oleh anak, tanpa diminta ataupun dibantu.

Berdasarkan berbagai pendapat di atas, maka terkait penelitian ini ciri-ciri kemandirian yang akan digunakan adalah menggabungkan pendapat dari
Martinis \& Jamilah dan Laman, Avery \& Frank yang memiliki beberapa kesamaan. Namun, dari 13 ciriciri kemandirian hanya diambil 5 sesuai dengan tahapan perkembangan anak, yaitu sebagai berikut:

a. Dapat melakukan aktivitasnya secara sendiri mesikipun tetap dengan pengawasan orang dewasa

b. Memiliki kemampuan untuk mengambil keputusan tanpa pengaruh dari orang lain

c. Dapat berhubungan dengan baik dengan orang lain

d. Memiliki kemampuan untuk bertindak sesuai dengan apa yang diyakini

e. Memiliki kemampuan untuk mencari dan mendapatkan kebutuhannya tanpa bantuan orang lain.

\section{Penanaman Kemandirian}

Kemandirian bukanlah sesuatu yang tiba-tiba saja muncul, tetapi tentu saja dapat tumbuh dan terbentuk dengan adanya berbagai faktor. Faktor-faktor tersebut dapat menghasilkan tingkat kemandirian seseorang berbeda-beda antara yang satu dengan yang lain. Wiyani mengemukakan bahwa faktorfaktor yang mendorong tumbuhnya kemandirian pada anak dibagi menjadi dua, yaitu faktor internal dan faktor eksternal. Faktor internal terdiri dari 2 kondisi yaitu kondisi fisiologis berupa keadaan tubuh, kesehatan jasmani, dan jenis kelamin dan kondisi psikologis berupa faktor bawaan. Sedangkan faktor eksternal meliputi lingkungan, rasa cinta dan kasih sayang, pola asuh orang tua dalam keluarga dan pengalaman dalam kehidupan. [10]

Menanamkan kemandirian pada anak dapat dilakukan dengan berbagai cara. Martinis \& Jamilah menuliskan bahwa ada beberapa hal yang menjadi perhatian dalam menanamkan kemandirian pada anak sejak dini, yaitu: a. Kepercayaan, b. Kebiasaan, c. Komunikasi, dan d. Disiplin. Perkembangan kemandirian menjadi salah satu hal yang harus diperhatikan dan ditanamkan sejak anak usia dini. Seperti yang tertuang di dalam Peraturan Menteri Nomor 146 Tahun 2014, Kompetensi Inti Sikap Sosial dalam KD-2 poin 2.8 yaitu memiliki perilaku yang mencerminkan kemandirian. [11]

\section{Sentra Balok}

Menurut Retno \& Wismiarti (dalam Latif), sentra mengandung makna "setiap kegiatan di semua sentra yang disediakan memiliki titik pusat (centre point), yang semuanya mengacu pada tujuan pembelajaran." Pendekatan sentra dan lingkaran adalah pendekatan penyelenggaraan pendidikan bagi anak usia dini yang berfokus pada anak dimana 
dalam proses pembelajarannya berpusat di sentra main dan saat anak dalam lingkaran. Terdapat empat jenis pijakan (scaffolding) dalam pelaksanaan kegiatan bermain di sentra yang digunakan untuk mendukung perkembangan anak, yaitu: (1) Pijakan lingkungan main; (2) Pijakan sebelum main; (3) Pijakan selama main; (4) Pijakan setelah main. [12]

Terdapat beberapa sentra yang dapat disediakan dan digunakan dalam proses pembelajaran, salah satunya adalah sentra balok. Rahaju menyatakan bahwa sentra balok berisi berbagai macam block (balok) dalam berbagai bentuk, ukuran, warna, dan tekstur. Di dalam sentra balok, anak belajar banyak hal dengan cara menyusun atau menggunakan balok, mengembangkan kemampuan logika matematika atau berhitung permulaan, kemampuan berpikir dan memecahkan masalah. [13]

Bermain balok merupakan salah satu jenis kegiatan yang sifatnya konstruktif, dimana anak mampu membangun sesuatu dengan menggunakan balokbalok yang sudah disediakan. Terdapat berbagai jenis balok sebagai alat main di sentra balok, diantaranya adalah balok unit. Tedjasaputra mengungkapkan bahwa bermain balok unit merupakan suatu permainan yang berbentuk bongkah kayu kecil yang mempunyai macammacam bentuk dan dapat menjadi suatu bentuk yang disukai dan diinginkan anak-anak. [14]

Berdasarkan buku Panduan Pendidikan Sentra untuk PAUD yang dikeluarkan Sekolah Al-Falah Surabaya, alat dan bahan main yang ada di sentra balok adalah sebagai berikut [15]:

a. Balok

Jumlah balok yang disediakan untuk tiap anak minimal 100 balok, 200 balok atau lebih dengan kelompok warna natural dari berbagai bentuk dan ukuran.

b. Alas Untuk Membangun

Alas berupa triplek yang dicat dengan ukuran, bentuk dan warna yang berbeda diletakkan di atas lantai dengan diberi jarak antara alas satu dengan alas lainnya sehingga membuat anak leluasa untuk bergerak.

c. Media Lain yang Digunakan/Alat Pendukung Sebagai alat pendukung dalam bermain balok, ada bermacam-macam alat-alat main peran mikro yang tersedia untuk memperluas pengalaman pembangunan ke main peran mikro, yaitu: keluarga binatang, orang-orangan, kendaraan, bahan-bahan tambahan, bahan-bahan keaksaraan dan set balok yang mewakili budaya yang berbeda untuk anak prasekolah dan pemain usia sekolah dasar.

Seluruh komponen tersebut di atas harus diperhatikan dan tersedia untuk mendukung kegiatan pembelajaran di sentra balok agar tercapainya tujuan pembelajaran secara optimal. Sentra balok sendiri memiliki tujuan dalam proses pembelajarannya, seperti yang diungkapkan oleh Latif, dkk bahwa tujuan dari sentra balok adalah membantu anak dalam meningkatkan kemampuan konstruksi mereka dari membuat susunan garis lurus ke atas ke representasi nyata dan dari bermain sendiri ke kemampuan bekerja dalam kelompok kecil, merencanakan, dan membangun.Bermain di sentra balok sendiri memberikan manfaat-manfaat bagi anak. Reifel, Phelps dan Hanline di dalam buku panduan Pendidikan Sentra Untuk PAUD (Sentra Balok) menuliskan manfaat bermain balok sebagai berikut [15]:

a. Ketrampilan berhubungan dan bekerjasama dengan teman sebaya

b. Kemampuan berkomunikasi

c. Kekuatan dan koordinasi motorik halus dan kasar

d. Konsep matematika dan geometri

e. Mengembangkan pemikiran simbolik

f. Pengetahuan pemetaan

g. Ketrampilan membedakan penglihatan.

Blogger (dalam Asmawati) juga mengungkapkan bahwa bermain balok memberikan manfaat, yaitu sebagai berikut [16]:
a. Belajar mengenai konsep
b. Belajar mengembangkan imajinasi
c. Melatih kesabaran
d. Secara sosial anak belajar berbagi
e. Mengembangkan rasa percaya diri anak

Di dalam buku yang ditulis oleh Children Resources International, Inc., dituliskan bahwa di pusat permainan balok, anak-anak bermain baik sendirisendiri maupun secara berkelompok menggunakan balok dengan berbagai bentuk serta ukuran. Dengan menggunakan balok, anak-anak dapat membuat bangunan-bangunan, mempelajari tentang ketinggian dan masa, mengenali bentuk, bekerjasama, meningkatkan koordinasi mata-tangan dan belajar bagaimana membersihkan dan menyimpan segala sesuatunya kembali. [17]

Pelaksanaan kegiatan bermain di sentra balok sendiri memiliki prosedur yang harus dipahami dan dilakukan oleh guru. Di dalam buku Panduan 
Pendidikan Sentra untuk PAUD Sekolah Al-Falah dijelaskan bahwa terdapat beberapa tahap yang harus dilakukan, yaitu:

a. Persiapan guru

Guru memilih alat atau bahan yang akan ditata dalam lingkungan main anak dan yang akan digunakan sebagai pijakan awal, sebagai alat motivasi untuk belajar tentang topik yang akan dipelajari, misal buku atau poster bangunan, bentuk-bentuk balok yang dipilih.

b. Penataan lingkungan

Guru sentra harus memastikan apakah penataan lingkungan main sudah sesuai dan siap untuk dimainkan oleh anak.Penataan lingkungan adalah guru ketiga bagi anak. Penataan lingkungan yang tepat dapat membantu anak dapat membuat prediksi apa yang akan dia lakukan dan yang apa akan dipelajari.

c. Pijakan awal

Guru menyambut anak yang datang lalu berkumpul pada alas yang berbentuk lingkaran, dimulai dengan nyanyian salam. Guru menjelaskan tema atau topik, konsep-konsep yang akan dipelajari melalui diskusi dengan anak.

Sebelum anak-anak bermain, guru menginformasikan tentang aturan main dan prosedur kerja sehingga anak-anak dapat teratur dalam bermain. Aturan yang diberlakukan bertujuan agar anak dapat mengontrol dirinya. Aturan bermain balok:

1. Balok untuk membangun

2. Membangun di atas alas

3. Mengambil balok secukupnya

4. Start-finish lancar

5. Bermain tepat waktu

6. Beres-beres

d. Saat main balok

Memberikan setiap anak waktu yang cukup (minimal 60 menit) untuk membangun dan main peran dengan hasil karya mereka. Guru bergerak di antara anak, sambil mengamati dan mencatat perkembangan anak sehingga guru dapat membuat hubungan dari apa yang dilihat sekarang dan tahapan sebelumnya, selain itu guru juga bergerak ke tempat anak yang membutuhkan pijakan secara individu dan mendorong serta memberi pijakan pada aktivitas anak selagi mereka membangun.

\section{e. Beres-beres}

Beres-beres adalah kegiatan penting dari sentra. Melalui kegiatan ini, guru terlibat langsung saat beres-beres. Anak menyimpan balok-balok ke tempat semula sesuai klasifikasi berdasarkan bentuk dan ukuran, sehingga penataan balokbalok dalam rak kembali rapi. Begitu pula dengan alas dan alat pendukung lainnya yang telah digunakan disimpan ke dalam wadah berdasarkan jenis alat dan dikembalikan ke dalam rak yang disusun dengan teratur dan rapi.

f. Recalling

Recalling adalah kegiatan dimana anak menceritakan kembali pengalaman main yang telah dilakukan dan alat apa yang telah digunakan. Saat recalling, anak dan guru berkumpul di karpet atau di kursi. Kemudian guru memberikan kesempatan kepada anak untuk menceritakan kembali pengalaman mainnya.

Berdasarkan uraian dalam pendahuluan di atas maka tujuan penelitian ini adalah mendeskripsikan upaya yang dilakukan dalam penanaman kemandirian anak melalui pembelajaran di sentra balok Taman Kanakkanak Islam Al Azhar 45 Grand Depok City.

\section{METODE}

Penelitian yang dilakukan di Taman Kanak-Kanak (TK) Islam Al Azhar 45 Grand Depok City ini menggunakan metode penelitian kualitatif. Penelitian dilakukan pada bulan Januari sampai dengan bulan Juli 2018. Subjek penelitian ini adalah anak-anak kelompok A4 yang berada di sentra balok TK Islam Al Azhar 45 Grand Depok City yang berjumlah 24 anak. Terdapat dua sumber data yang digunakan yaitu sumber data primer berupa anak kelompok A4 berjumlah 24 orang yang berada di sentra balok, kepala sekolah, guru kelas dan guru sentra balok, dan sumber data sekunder berupa hasil dokumentasi aktivitas 24 anak kelompok A4 saat proses pembelajaran di sekolah selama satu hari, serta RPPM, RPPH dan penilaian kegiatan. 
Adapun indikator kemandirian yang akan diamati adalah: 1). Dapat melakukan aktivitasnya secara sendiri mesikipun tetap dengan pengawasan orang dewasa; 2). Memiliki kemampuan untuk mengambil keputusan tanpa pengaruh dari orang lain; 3). Dapat berhubungan dengan baik dengan orang lain; 4). Memiliki kemampuan untuk bertindak sesuai dengan apa yang diyakini; serta 5). Memiliki kemampuan untuk mencari dan mendapatkan kebutuhannya tanpa bantuan orang lain.

Teknik pengumpulan data yang digunakan adalah observasi, wawancara dan dokumentasi. Analisis data menggunakan teknik analisis data Model Interaktif dari Miles and Huberman yaitu reduksi data, penyajian data dan verifikasi data. Data disajikan dalam bentuk narasi dan gambar. [18]

\section{HASIL DAN PEMBAHASAN}

Taman Kanak-Kanak Islam Al Azhar 45 Grand Depok City adalah lembaga pendidikan Islam yang dikelola oleh Yayasan Pendidikan Budi Insan Cendikia bekerjasama dengan Yayasan Pesantren Islam Al Azhar Kebayoran Baru, Jakarta.Model pembelajaranyang digunakan TK Islam Al Azhar 45 Grand Depok City adalah model pembelajaran Sentra. Terdapat 8 sentra yang disediakan Grand Depok City, yaitu sentra sentra makro, sentra mikro, sentra agama, sentra seni, sentra persiapan, sentra balok, sentra bahan alam, sentra olah tubuh dan sentra teknologi informasi.

Seluruh sentra yang disediakan harus dapat menstimulus 6 aspek perkembangan anak yaitu: perkembangan moral agama, fisik motorik, sosial emosional, kognitif, bahasa, dan seni, dan pembagian sentra-sentra main ini adalah untuk mengkategorikan variasi bentuk permainan yang menstimulus aspek perkembangan tersebut. Bentuk stimulus seluruh aspek tersebut dilakukan sejak anak datang ke sekolah dengan melakukan ikrar, kegiatan pembuka/morning meeting, kegiatan inti (sentra) dan penutup.

Proses pembelajaran di sentra balok dimulai pukul 10.00 sampai dengan pukul 12.00. Dalam pelaksanaannya sentra balok memiliki 4 pijakan yang harus dilakukan oleh guru selama proses pembelajaran. Pijakan yang pertama yaitu pijakan lingkungan main, yang dilakukan guru pada saat itu adalah mempersiapkan lingkungan main, seperti mempersiapkan media dan menata kelas. Berbeda dengan sentra-sentra lainnya, sentra balok terbilang cepat dan mudah dalam mempersiapkannya, karena media pembelajaran hanya berupa balok dan balok sudah tertata rapi disusun sesuai dengan bentuknya di rak, sehingga yang harus dipersiapkan guru adalah menentukan balok mana yang akan dibuka dan boleh digunakan, serta meletakkan papan alas dan keranjang pada posisi bermain.

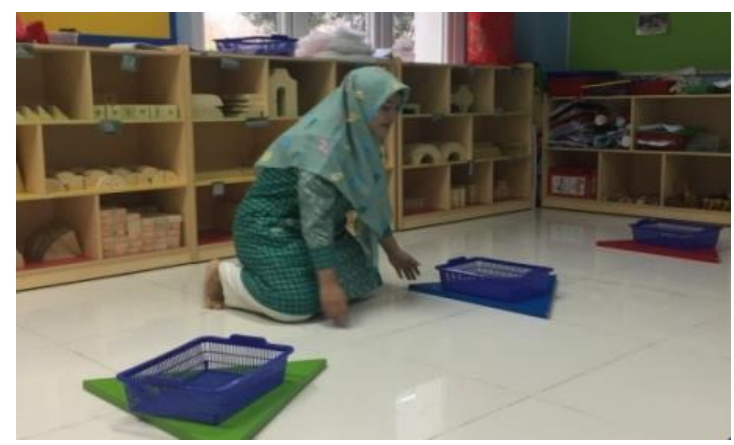

Gambar 1. Guru menata lingkungan main pada tahap pijakan lingkungan main

Penanaman kemandirian mulai terlihat saat pijakan yang kedua sampai dengan pijakan yang keempat. Pijakan yang kedua adalah pijakan sebelum bermain, yang dilakukan guru pada saat itu adalah mengucapkan salam, kemudian berdiskusi dan melakukan tanya jawab mengenai tema yang dibahas pada hari itu. Kegiatan selanjutnya adalah memberitahu macam-macam bentuk balok dan cara menyusun balok. Selain itu juga disampaikan peraturan bermain di sentra balok yang telah diketahui oleh anak karena selalu disampaikan guru sebelum kegiatan bermain dimulai. Peraturan bermain di sentra balok yaitu: 1). mengambil dan mengembalikan balok ke tempatnya; 2). sayang teman; 3).baloknya dijaga; 4). Fokus; 5). baloknya boleh berbagi dengan teman; dan 6). ambil balok secukupnya.

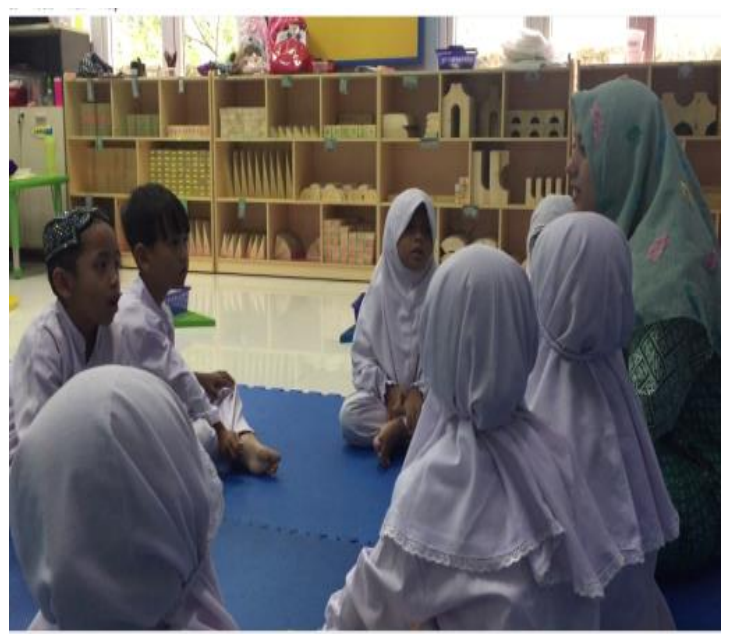

Gambar 2. Pijakan sebelum main 
Peraturan yang pertama adalah "mengambil dan mengembalikan balok ke tempatnya". Dengan adanya peraturan ini anak-anak akan mengerti bahwa anak-anak dapat mengambil balok yang tersedia di rak sesuai jumlah yang dibutuhkan namun setelah selesai bermain mereka harus mengembalikan balok sesuai dengan bentuknya di rak balok tempat anak mengambilnya semula. Hal tersebut sesuai dengan pendapat dari Yamin \& Sabri yang menjelaskan ciri-ciri anak yang mandiri salah satunya adalah dapat melakukan segala aktifitasnya secara sendiri meskipun tetap dengan pengawasan orang dewasa. Dalam hal ini, anak-anak akan belajar untuk mandiri bahwa setelah mengambil balok dan memainkannya, ketika sudah selesai bermain maka harus merapikannya sendiri, bukan orang lain yang mengerjakan melainkan dirinya sendiri.

Peraturan yang kedua adalah "baloknya dijaga". Adanya peraturan ini akan membuat anak mengerti bahwa balok tidak boleh dilempar, tidak boleh untuk memukul teman, tetapi harus dirawat dengan baik. Peraturan yang ketiga adalah "baloknya boleh berbagi dengan teman". Peraturan ketiga ini mengajarkan anak untuk mengerti bahwa semua balok yang ada adalah milik bersama jadi dalam penggunaannya harus berbagi dengan temannya, dengan cara saling bertukar dan saling meminjamkan.

Peraturan kedua dan ketiga memiliki kesamaan dan kesesuaian dengan pendapat yang disampaikan oleh Laman, Avery \& Frank yang menyebutkan ciri - ciri individu yang mandiri salah satunya adalah dapat berhubungan dengan baik dengan orang lain. Dalam hal ini, anak-anak akan belajar bersikap baik dengan temannya, harus sayang kepada temannya dan anakanak juga akan belajar untuk berbagi.

Peraturan yang keempat adalah "ambil balok secukupnya." Melalui peraturan ini anak diajarkan untuk mengerti bahwa tidak perlu berlebihan saat mengambil balok meskipunn balok yang disediakan cukup banyak. Apabila anak mengambil balok terlalu banyak maka akan membutuhkan waktu yang lama dalam pengambilan maupun dalam pengembalian balok tersebut ke tempat semula. Laman, Avery \& Frank yang menyebutkan ciri - ciri individu yang mandiri salah satunya adalah memiliki kemampuan untuk bertindak sesuai dengan apa yang diyakini. Dalam hal ini, anak-anak akan belajar berpikir mandiri bahwa apabila anak mengambil balok terlalu banyak maka teman yang lain mungkin tidak akan bisa mendapatkan balok yang mereka butuhkan. Selain itu anak mungkin juga akan merasa malas untuk mengembalikan karena jumlah balok yang terlalu banyak.

Aturan yang disampaikan guru sebelum anak-anak melakukan kegiatan main terlihat ada perbedaan dengan aturan yang dirumuskan dalam buku panduan Pendidikan Sentra untuk PAUD yang dikeluarkan oleh sekolah Al Falah, Jakarta. Al Falah Jakarta merumuskan aturan main sebagai berikut: balok untuk membangun; membangun di atas alas; mengambil balok secukupnya; start-finish lancar; bermain tepat waktu; dan beres-beres. Sedangkan aturan yang disampaikan guru di sekolah Al Azhar Grand Depok City adalah sebagai berikut: mengambil dan mengembalikan balok ke tempatnya; sayang teman; baloknya dijaga; fokus; baloknya boleh berbagi dengan teman; dan ambil balok secukupnya.

Namun meskipun terdapat perbedaan, hal yang utama adalah kedua sekolah memiliki aturan yang harus dilaksanakan oleh anak ketika mereka bermain. Adanya aturan tersebut menjadi panduan mengenai apa yang boleh dan tidak boleh dilakukan serta menjadi tujuan dari kegiatan pembelajaran yang dilakukan, utamanya di sentra balok, yang salah satunya adalah dalam upaya penanaman kemandirian untuk anak.

Setelah menyebutkan aturan dalam bermain di sentra balok, guru memberikan 4 kosa kata pada anak. Kosa kata yang disebutkan adalah segala sesuatu yang berhubungan dengan tema atau pembelajaran pada hari itu. Guru akan mengulangulang kosa kata dan setelah anak-anak hafal, guru bertanya dan anak yang bisa menjawab boleh memilih teman bermain berdua sampai bertiga. Setelah itu anak boleh langsung bermain. Kegiatan bermain diawali dengan anak mengambil balok di rak menggunakan keranjang sesuai dengan yang dinginkan dan dibutuhkan. Setelah itu anak-anak mulai menyusun balok bersama-sama dengan temannya.

Pijakan yang ketiga adalah pijakan selama main. Pada pijakan ini, guru mengingatkan anak-anak kembali bagaimana cara bermain balok serta peraturan bermain di sentra. Pada saat anak bermain, guru berkeliling melihat anak "bekerja" sambil melakukan penilaian terhadap bangunan yang disusun oleh anak-anak. 


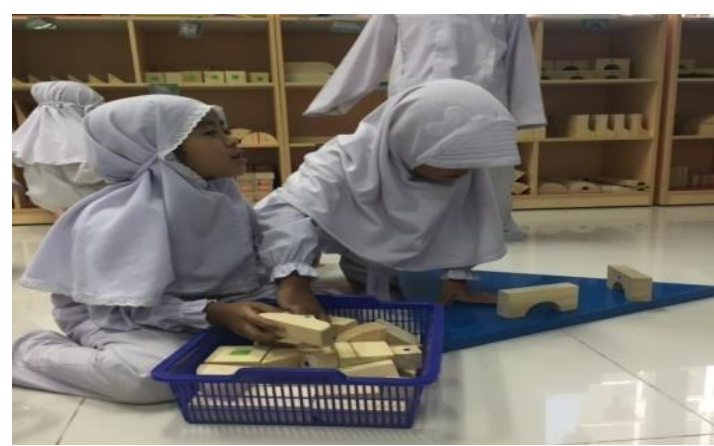

Gambar 3 Pijakan selama main

Gambar 4 Anak menunjukan hasil karyanya

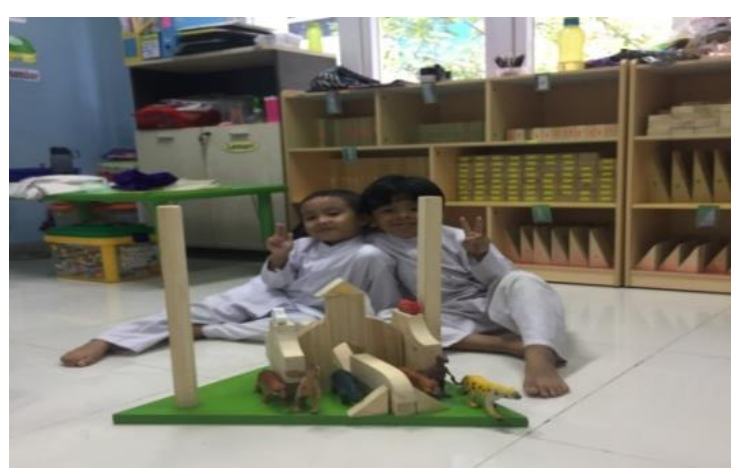

Pijakan yang keempat adalah pijakan setelah bermain, yang dilakukan guru pada saat itu adalah recalling. Guru bertanya apa yang sudah dibuat anak dan memberikan kesempatan kepada anak untuk menceritakan apa yang sudah dibuat dan terdapat apa saja di dalamnya. Setelah waktu bermain habis guru menginformasikan kepada anak-anak untuk melakukan beres-beres mengembalikan balok-balok ke dalam rak sesuai dengan bentuknya, mengembalikan papan alas serta keranjang ke tempat semula.

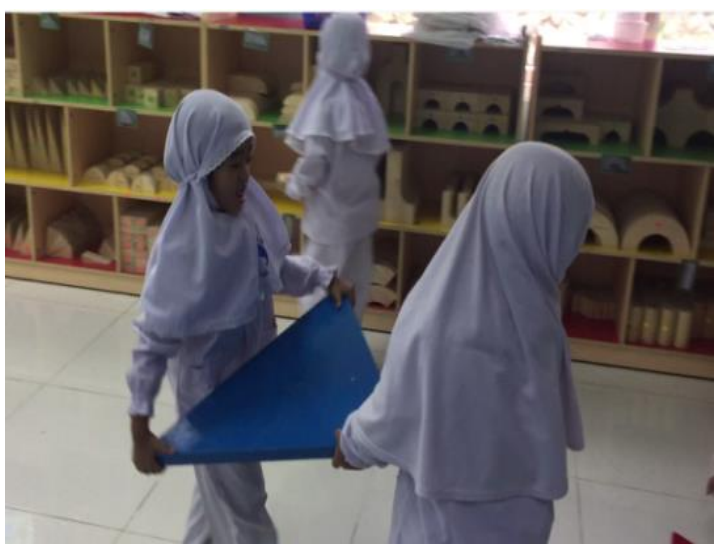

Gambar 4 Anak bekerjasama saat beres-beres

Proses penanaman kemandirian pada anak melalui pembelajaran di sentra balok, dapat juga disajikan dalam bentuk tabel berikut.
Tabel 1 Proses Penanaman Kemandirian

\begin{tabular}{|c|c|c|c|}
\hline No & $\begin{array}{c}\text { Aspek } \\
\text { Kemandirian }\end{array}$ & $\begin{array}{c}\text { Penanaman } \\
\text { Kemandirian }\end{array}$ & $\begin{array}{c}\text { Contoh Kegiatan } \\
\text { Kemandirian }\end{array}$ \\
\hline 1. & $\begin{array}{l}\text { Dapat melakukan } \\
\text { aktivitasnya } \\
\text { sendiri meskipun } \\
\text { tetap dengan } \\
\text { pengawasan } \\
\text { orang dewasa }\end{array}$ & $\begin{array}{l}\text { mengambil dan } \\
\text { mengembalikan } \\
\text { balok ke } \\
\text { tempatnya }\end{array}$ & 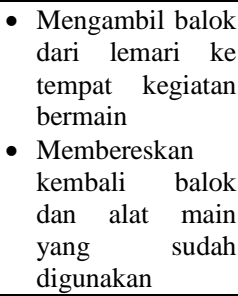 \\
\hline 2. & $\begin{array}{l}\text { Memiliki } \\
\text { kemampuan } \\
\text { untuk mengambil } \\
\text { keputusan tanpa } \\
\text { pengaruh dari } \\
\text { orang lain }\end{array}$ & $\begin{array}{l}\text { ambil balok } \\
\text { secukupnya }\end{array}$ & 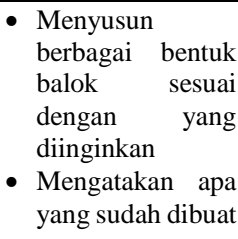 \\
\hline 3. & $\begin{array}{l}\text { Dapat } \\
\text { berhubungan } \\
\text { dengan orang lain }\end{array}$ & $\begin{array}{l}\text { baloknya dijaga } \\
\text { baloknya boleh } \\
\text { berbagi dengan } \\
\text { teman }\end{array}$ & $\begin{array}{l}\text { - } \text { Berbagi balok } \\
\text { dengan temannya } \\
\text { - Bekerjasama } \\
\text { dengan temannya } \\
\text { dalam menyusun } \\
\text { balok }\end{array}$ \\
\hline 4. & $\begin{array}{l}\text { Memiliki } \\
\text { kemampuan } \\
\text { untuk bertindak } \\
\text { sesuai dengan } \\
\text { apa yang diyakini }\end{array}$ & $\begin{array}{l}\text { Ambil balok } \\
\text { secukupnya }\end{array}$ & $\begin{array}{l}\text { - Menyusun balok } \\
\text { sesuai dengan } \\
\text { imajinasi } \\
\text { - Memainkan peran } \\
\text { mikro ketika } \\
\text { selesai menyusun } \\
\text { bangunan balok }\end{array}$ \\
\hline 5. & $\begin{array}{l}\text { Memiliki } \\
\text { kemampuan } \\
\text { untuk mencari } \\
\text { dan mendapatkan } \\
\text { kebutuhannya } \\
\text { tanpa bantuan } \\
\text { orang lain }\end{array}$ & $\begin{array}{l}\text { Ambil balok } \\
\text { secukupnya } \\
\text { Baloknya boleh } \\
\text { berbagi dengan } \\
\text { teman }\end{array}$ & 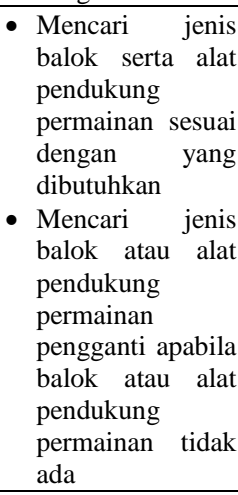 \\
\hline
\end{tabular}

\section{KESIMPULAN}

Penanaman kemandirian di sentra balok dilakukan oleh guru melalui penerapan aturan main yang disampaikan guru secara konsisten pada saat pijakan sebelum main. Dari beberapa aturan main yang disampaikan guru, 4 aturan main merupakan upaya penanaman kemandirian pada anak. Keempat aturan tersebut adalah mengambil dan mengembalikan balok ke tempatnya; baloknya dijaga; baloknya boleh berbagi dengan teman; danambil balok secukupnya.

Penerapan keempat aturan main tersebut dapat menumbuhkan kemandirian anak dalam bentuk: dapat melakukan aktivitasnya sendiri; dapat mengambil keputusan tanpa pengaruh dari orang 
lain; dapat berhubungan baik dengan orang lain; dapat bertindak sesuai dengan apa yang diyakininya; serta mampu mencari dan mendapatkan apa yang dibutuhkannya tanpa bantuan orang lain.

Adapun saran yang dapat diberikan yaitu: pertama, guru hendaknya menguasai seluruh prosedur pelaksanaan pembelajaran yang ada di sentra balok dengan cara mempelajari dan mendalami kembali prosedur pembelajaran dengan model pembalajaran sentra; kedua, Kepala Sekolah, hendaknya dapat memfasilitasi guru untuk mengikuti pelatihanpelatihan terkait pembelajaran di sentra, agar setiap guru memiliki kesamaan baik pemahaman maupun penerapan dalam setiap pembelajaran yang diberikan kepada anak serta membuat peraturan secara tertulis agar dapat diketahui, dipahami, dan dilakukan oleh seluruh guru yang mengajar di sentra balok.

\section{REFERENSI}

[1] S. Yusuf, 'Psikologi Perkembangan Anak dan Remaja”, Bandung: PT Remaja Rosda Karya, 2009.

[2] Monks, dkk, "Psikologi perkembangan: pengantar dalam berbagai bagian", Yogyakarta: Gadjah Mada University Press, 1994.

[3] Pusat Kurikulum Balitbang Departemen Pendidikan Nasional. 'Standar Isi Pendidikan Anak Usia Dini”, Jakarta, 2007.

[4] Fadholi, Muhammad. "Tingkat Kemandirian Anak Usia Pra Sekolah Ditinjau dari Pola Asuh Demokratis". [Thesis]. Universitas Muhammadiyah Surakarta.2011.

[5] Y. Nurfalah, Panduan Praktis Melatih Kemandirian Anak Usia Dini, Bandung: PNFI Jayagiri, 2010.

[6] A. Budinurani, "Kemandirian Pada Remaja Putra Yang Menikah Muda" [Skripsi], Universitas Gunadarma, 2009.
[7] Y. Martinis, Jamilah, S. Sanan, "Panduan Pendidikan Anak Usia Dini”. Ciputat: Gaung Persada Press Group, 2013.

[8] Ambarsari, Ema; Syukri, M.; dan Miranda, Dian. Peningkatan Kemandirian Anak Melalui Metode Pembiasaan Usia 4-5 tahun di Taman Kanak-KanakMujahidin 1. Jurnal Pendidikan dan Pembelajaran Vol. 3, No. 9, September 2014 http://id.portalgaruda.org/index.php?ref=bro wse $\&$ mod $=$ viewarticle \&article $=174887$

[9] http://peraturan.go.id/uu/nomor-20-tahun2003.html. http://peraturan.go.id/inc/view/11e44c4ebd4c b9008216313231363139.html

[10] N. A. Wiyani, "Bina Karakter Anak Usia Dini: anduan Orangtua \& Guru dalam Membentuk Kemandirian \& Kedisiplinan Anak Usia Dini”. Jogjakarta: Ar-Ruzz Media. 2013.

[11] Peraturan Menteri Nomor 146. 2014. Kurikulum 2013 Pendidikan Anak Usia Dini. Jakarta.

[12] M. Latif, dkk. 'Orientasi Baru Pendidikan Anak Usia Dini. Jakarta: Kencana Prenada Media Group. 2013.

[13] I. Rahaju, "Analisis Penyelengaraan Pendidikan Anak Usia Dini Yang Menggunakan Model Beyond Center And Circle Time”.2014.

[14] M. S. Tedjasaputra, "Bermain, Mainan dan Permainan untuk Pendidikan Anak Usia Dini." Jakarta:Gramedia Pustaka. 2001.

[15] Panduan Pendidikan Sentra Untuk PAUD (Sentra Balok). Jakata: Pustaka Al-Falah.

[16] Asmawati,.dkk. "Pengelolaan kegiatan Pengembangan Anak Usia Dini". Jakarta: Universitas Terbuka. 2008.

[17] Children Resources International, Inc. "Menciptakan Kelas yang Berpusat pada Anak". Jakarta. 2000.

[18] Sugiyono. "Memahami Penelitian Kualitatif". Bandung: Penerbit Alfabeta. 2014. 